\title{
EFEK PEMORDANAN TERHADAP PEWARNAAN MENGGUNAKAN KOMBINASI LIMBAH CAIR GAMBIR DAN EKSTRAK KAYU SECANG PADA KAIN RAYON DAN KATUN
}

\section{Mordant Effects on Dyeing of Gambier Liquid Waste and Secang Wood Extract Combination on Rayon and Cotton Fabrics}

\author{
F. Failisnur*, S.Sofyan, dan Robby Kumar \\ Balai Riset dan Standardisasi Indusri Padang \\ JI.Raya LIK No.23 Ulu Gadut, Padang, Indonesia \\ *e-mail: failisnur@gmail.com
}

Diterima: 11 Desember 2017, revisi akhir: 19 Desember 17 dan disetujui untuk diterbitkan: 21 Desember 2017

\begin{abstract}
ABSTRAK
Kombinasi limbah cair gambir dan kayu secang (Caesalpinea sappan L.) dapat menambah variasi warna kain yang dicelup dengan pewarna alami. Penelitian ini menjelaskan tentang efek pewarnaan kombinasi limbah cair gambir dan kayu secang dengan metoda dan jenis mordan yang berbeda terhadap arah warna dan karakteristik lainnnya dari kain rayon dan katun hasil celupan. Proses mordan yang digunakan adalah 1 kali dan 2 kali mordan menggunakan $\left.\mathrm{CaO}, \mathrm{Al}_{2} \mathrm{SO}_{4}\right)_{3}, \mathrm{FeSO}_{4}$ yang dibandingkan dengan tanpa mordan. Kain hasil pewarnaan dievaluasi arah warna, intensitas warna (K/S), dan ketahanan luntur warna. Hasil penelitian menunjukkan arah warna kain rayon dan katun yang lebih bervariasi. Serat rayon memiliki afinitas dan penyerapan yang lebih besar terhadap zat warna limbah cair gambir dan kayu secang dibandingkan dengan serat selulosa. Proses mordan dapat meningkatkan intensitas warna (K/S) dan ketahanan luntur warna terhadap pencucian, keringat asam, gosokan, dan sinar.
\end{abstract}

Kata kunci: limbah cair gambir, ekstrak kayu secang, arah warna, intensitas warna, ketahanan luntur warna

\begin{abstract}
Combination of gambier liquid waste and secang wood (Caesalpinea sappan L.) can add color variations of fabric dyed with natural dyes. This research explained the effect of dyeing combination of gambir liquid waste and secang wood with different mordant method and type on the color shade and other characteristics of rayon and cotton dyed fabric. The mordant process was performed as much as 1 and 2 times using $\mathrm{CaO}, \mathrm{Al}\left({ }_{2} \mathrm{SO}_{4}\right)_{3}, \mathrm{FeSO}_{4}$ mordant and then compared without mordant treatment. The result of the dyed fabrics was evaluated the color shade, color strength (K/S), and fastness properties. The results showed that the color shade of rayon and cotton fabrics were varied. Rayon fibers had a greater affinity and absorption to the liquids waste of gambier and secang wood than in cellulose fibers. The mordant process could increase color strength (K/S) and color fastness to washing, acidic perspiration, rubbing, and light.
\end{abstract}

Keywords: gambier liquid waste, secang wood extract, color shade, color strength, color fastness properties

\section{PENDAHULUAN}

Eksplorasi dari tanaman gambir
(Uncaria gambir Roxb.) telah banyak
dilakukan. Beberapa penelitian yang
mengkaji pemanfaatan tanaman ini
diantaranya adalah pengembangan gambir

menjadi bahan baku produk farmasi dan kosmetik (Yeni et al., 2017), penyamak kulit (Arbain et al., 2014; Yeni et al., 2016), tinta stempel (Silfia et al., 2015) dan pewarna tekstil (Failisnur and Yeni, 2013).

Gambir dan limbah cair gambir sebagai pewarna tekstil telah banyak 
dipelajari. Pewarna ini telah diaplikasikan untuk mewarnai kain katun (Sofyan et al., 2015), rayon (Failisnur et al., 2017; Sofyan and Failisnur, 2016), sutera (Failisnur and Sofyan, 2014; Failisnur and Yeni, 2013) dan benang tenun (Failisnur and Sofyan, 2016; Sofyan and Failisnur, 2017). Proses pewarnaan juga dilakukan pada kain batik (Failisnur et al., 2017; Sofyan and Failisnur, 2016).

Kain hasil pencelupan dengan pewarna gambir memberikan warna yang cenderung kecoklatan, mulai dari kuning kecoklatan, coklat kemerahan dan coklat kehitaman (Failisnur and Sofyan, 2014). Secara visual, arah warna kain dari beberapa konsentrasi gambir, penggunaan jenis mordan, suhu dan waktu pencelupan terlihat berbeda. Akan tetapi, pengamatan melalui instrumentasi menyatakan bahwa warna-warna kain berada pada panjang gelombang yang sama ( $\lambda \max 400 \mathrm{~nm})$ (Failisnur and Sofyan, 2016, 2014; Sofyan et al., 2015). Hal ini menjelaskan bahwa warna dari kain hasil pencelupan memiliki ruang warna yang sama.

Keterbatasan ini dapat diatasi dengan mengkombinasikan pewarna gambir dengan pewarna alam lainnya. Pewarna kombinan diambil dari tanaman lain yang memberikan warna dengan nuansa yang berbeda. Beberapa tanaman yang menghasilkan nuansa warna yang berbeda diantaranya adalah ekstrak daun alpukat dan kayu nangka yang memberikan nuansa warna kekuningan (Prayitno et al., 2014; Rosyida, 2015). Warna ini hampir sama dengan pewarnaan gambir menggunakan mordan tawas. Sementara dengan pewarnaan menggunakan kayu secang, dapat memberikan nuansa warna merah keunguan.

Kayu Secang (Caesalpinea sappan L.) memiliki kandungan senyawa brazilin $\left(\mathrm{C}_{16} \mathrm{H}_{14} \mathrm{O}_{5}\right)$, sappanin $\left(\mathrm{C}_{12} \mathrm{H}_{12} \mathrm{O}_{4}\right)$ dan brazilein (Fu et al., 2008; Sugiyanto et al., 2013). Dalam pewarnaan, kayu secang dapat memberikan warna merah cerah pada makanan dan minuman (Holinesti, 2007). Pigmen brazilein memiliki warna merah tajam yang cerah pada $\mathrm{pH}$ netral (pH 6-7) dan bergeser kearah merah keunguan dengan semakin meningkatnya $\mathrm{pH}$. Pada $\mathrm{pH}$ rendah $(\mathrm{pH} 2-5)$ brazilein memiliki warna kuning. Penggunaan mordan kalsium (ion $\mathrm{Ca}^{+2}$ ) yang bersifat basa, menunjukkan warna merah jambu lebih tua dari pada menggunakan mordan aluminium (Fardhayanti and Riski, 2015).

Penelitian ini bertujuan untuk mengamati arah warna yang dihasilkan pada kain rayon dan katun melalui kombinasi pewarnaan menggunakan limbah cair gambir dan kayu secang. Bertambahnya variasi warna yang dihasilkan dapat memperluas tingkat penerimaan terhadap kain dengan pewarna alam terutama dari limbah cair gambir. Sementara intensitas dan ketahanan luntur warnanya ditingkatkan melalui perlakuan mordan yang digunakan.

\section{METODOLOGI PENELITIAN}

\section{Bahan dan Alat}

Pewarna yang digunakan adalah limbah cair gambir yang diambil dari Taeh Bukit Kabupaten 50 Kota, Propinsi Sumatera Barat. Pewarna kombinannya digunakan kayu secang, yang disuplai dari pasar Kota Padang. $\left.\mathrm{CaO}, \mathrm{Al}_{2} \mathrm{SO}_{4}\right)_{3}, \mathrm{FeSO}_{4}$ digunakan sebagai mordan. Kain yang diwarnai adalah kain viskos dan katun primissima dari Jogyakarta. Analisis kadar tanin menggunakan indigo carmin, gelatin, $\mathrm{NaCl}, \mathrm{H}_{2} \mathrm{SO}_{4}$, bubuk kaolin, $\mathrm{KMnO}_{4}$, dan aquades. Peralatan yang digunakan diantaranya timbangan analitis Kern: $A B S$ 220-4 Analytical balance, Spektofotometer Colorscan SS 6200, Hunter lab color flex, Laundry meter, dan Crock meter.

\section{Pelaksanaan}

1. Ekstraksi kayu secang (Fardhayanti and Riski, 2015)

Proses ekstraksi kayu secang dilakukan sebagai berikut; a) Kayu secang sebanyak $1 \mathrm{~kg}$ direndam dalam $20 \mathrm{~L}$ air, b) Maserasi selama 1 malam, c) Larutan pewarna direbus sampai mendidih, d) Pemanasan dilanjutkan sampai larutan tinggal setengahnya, dan e) Ekstrak yang diperoleh disaring 400 mesh dan siap digunakan untuk mewarnai kain.

\section{Mordanting \\ Metoda mordan yang dilakukan adalah pasca mordanting, dimana proses}


perendaman kain dalam larutan mordan dilakukan setelah kain dicelup dengan zat warna alam (Kumaresan, 2013; Moiz et al., 2010; Samanta and Agarwal, 2009; Samanta and Konar, 2011). Konsentrasi zat mordan yang dipakai adalah $\mathrm{CaO} 5 \%$, $\left.\mathrm{Al}_{2} \mathrm{SO}_{4}\right)_{3} 7 \%$, FeSO4 3\% pada rasio $1: 20$ (berat kain/volume) (Failisnur and Sofyan, 2016). Proses pewarnaan dilakukan pada suhu $70^{\circ} \mathrm{C}$ selama 30 menit pada rasio perbandingan berat/volume 1:30 (Failisnur and Sofyan, 2016, 2014).

Limbah cair gambir dipanaskan sampai mendidih lebih kurang 30 menit, kemudian dibiarkan dingin sebelum digunakan. Perlakuan penelitian dilakukan dengan memvariasikan jenis kain (viskos dan katun) dan proses satu kali, dua kali pemordanan dan kontrol (tanpa mordan) menggunakan jenis mordan $\mathrm{CaO}$, $\left.\mathrm{Al}_{2} \mathrm{SO}_{4}\right)_{3}, \mathrm{FeSO}_{4}$.

\section{Proses pewarnaan}

Proses pewarnaan terhadap kain katun dan rayon dilakukan melalui beberapa tahapan. Proses pewarnaan adalah sebagai berikut; a) Kain dicelup dalam larutan limbah cair gambir, kemudian dikeringkan, b) Kain yang telah kering, dicelup dalam larutan mordan masingmasing $\left.\mathrm{CaO}, \mathrm{Al}_{2} \mathrm{SO}_{4}\right)_{3}, \mathrm{FeSO}_{4}$, kemudian dikering anginkan, c) Kain dicelup dalam larutan secang $(1 ; 30)$ kemudian dikering anginkan, d) Setengah bagian kain dicelup dalam larutan mordan masing-masing $\left.\mathrm{CaO}, \mathrm{Al}_{2} \mathrm{SO}_{4}\right)_{3}, \mathrm{FeSO}_{4}$ kemudian dikering kan. Kain yang telah kering lalu dicuci sampai bersih, e) Setengah bagian lagi dari kain langsung dicuci sampai bersih tanpa dicelup dalam larutan mordan, dan f). Kain warna kemudian diuji intensitas, koordinat warna dan ketahanan luntur warnanya.

\section{Pengamatan}

\section{Intensitas dan koordinat warna}

Pengamatan dilakukan terhadap kain viskos dan katun yang telah diwarnai meliputi; intensitas warna (K/S) menggunakan Spectrophotometer Premier Colorscan SS 6200. Intensitas warna didapat dengan mengukur persen reflektansi (\% R) yang dikonversikan ke nilai K/S berdasarkan persamaan Kubelka-
Munk (persamaan 1) (Mirjalili and Karimi, 2013).

$$
\mathrm{K} / \mathrm{S}=\frac{(1-\mathrm{R})^{2}}{2 \mathrm{R}}
$$

Keterangan:

Koefisien absorpsi (cahaya yang diserap) (K), Koefisien cahaya yang disebarkan (S), Nilai persen reflektansi pada $\lambda$ maksimum (R).

Uji beda warna dengan menggunakan metode CIELAB 1976, berdasarkan ruang koordinat warna yaitu kecerahan warna (brightness) $\left(\mathrm{L}^{*}\right)$, kemerahan $\left(+\mathrm{a}^{*}\right)$, kehijauan $\left(-a^{*}\right)$, kekuningan $\left(+b^{*}\right)$, dan kebiruan (-b*) (Zhao et al., 2014).

\section{Ketahanan luntur warna}

Ketahanan luntur warna diukur dengan menggunakan standar grey scale dan staining scale. Ketahanan luntur warna meliputi; Ketahanan luntur warna terhadap pencucian $40^{\circ} \mathrm{C}$ (perubahan dan penodaan warna) berdasarkan BSN, 2010: SNI ISO 105-C 06, sinar terang hari (BSN, 2010: SNI ISO 105-B01), gosokan (BSN, 2008: SNI 0288-2008), dan keringat asam dan basa (BSN, 2010: SNI ISO 105-E04).

\section{HASIL DAN PEMBAHASAN}

\section{Hasil Pewarnaan, Intensitas dan Koordinat Warna}

Secara visual, perlakuan kombinasi pewarna dan mordan yang digunakan memberikan pengaruh yang nyata terhadap arah kain rayon dan kain katun (Tabel 1). Dari kedua jenis kain yang digunakan, terlihat rayon menyerap zat warna lebih tinggi dibandingkan dengan kain katun. Hal ini dapat dilihat secara visual dimana arah warna kain rayon lebih tua dan nilai K/S lebih tinggi dibandingkan kain katun.

Pada kain rayon, proses mordanting meningkatkan intensitas warna kain pada seluruh perlakuan. Arah warna berubah pada satu kali pemordanan dan semakin meningkat setelah dua kali proses mordanting. Arah warna berubah dari keunguan (kontrol) menjadi coklat kemerahan (dengan logam $\mathrm{Al}$ ), coklat tua (dengan logam $\mathrm{Ca}$ ) dan abu-abu kehitaman (dengan logam Fe) (Tabel 1). Kondisi ini 
diperkuat dengan meningkatnya intensitas warna (K/S) (Tabel 2).

Pada kain katun, setelah satu kali mordan terjadi peningkatan nilai K/S (Tabel 2) dan arah warna kain menjadi lebih kuat (Tabel 1). Sedangkan pada proses mordan kedua, hanya mordan $\mathrm{Fe}$ dan $\mathrm{Ca}$ yang mampu meningkatkan nilai K/S dan arah warna menjadi lebih tua, sedangkan dengan mordan Al terjadi penurunan nilai $\mathrm{K} / \mathrm{S}$. Pada beberapa pewarnaan alami, mordan Al membentuk ikatan yang lemah dengan pewarna (Khattak et al., 2014; Moiz et al., 2010; Punrattanasin et al., 2013).

Tabel 1. Hasil pewarnaan kombinasi kayu secang dengan limbah gambir

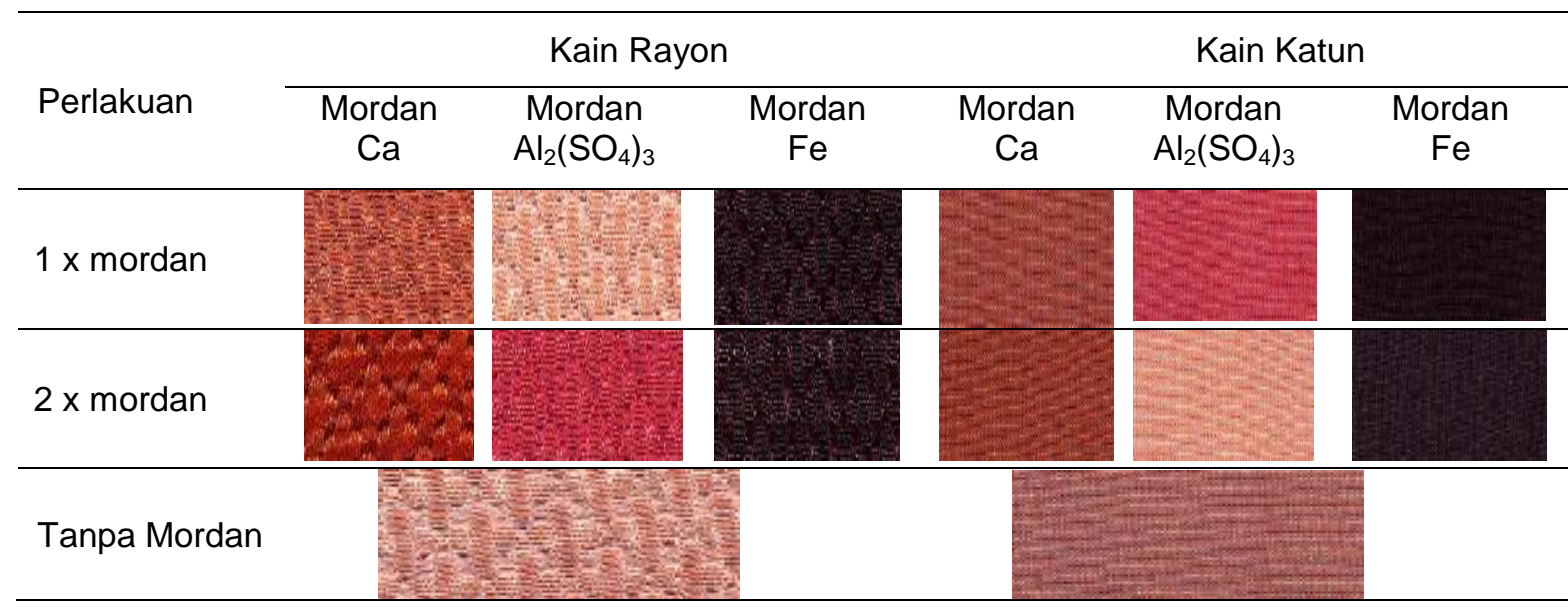

Sumber: Data Hasil Penelitian Sendiri

Tabel 2. Pengukuran arah warna dan intensitas warna

\begin{tabular}{|c|c|c|c|c|c|c|}
\hline Perlakuan & Jenis Kain & $\begin{array}{l}\text { Jenis } \\
\text { Mordan }\end{array}$ & $\mathrm{K} / \mathrm{S}$ & $L^{*}$ & $a^{*}$ & $b^{*}$ \\
\hline \multirow{8}{*}{$1 \times$ Mordan } & \multirow{4}{*}{ Rayon } & $\mathrm{CaO}$ & 4,0107 & 59,26 & 13,08 & 1,23 \\
\hline & & $\mathrm{Al}_{2}\left(\mathrm{SO}_{4}\right)_{3}$ & 2,7062 & 54,60 & 27,57 & 12,53 \\
\hline & & $\mathrm{FeSO}_{4}$ & 4,5641 & 36,33 & 6,39 & 1,23 \\
\hline & & Kontrol & 1,7414 & 68,94 & 7,27 & 12,75 \\
\hline & \multirow{4}{*}{ Katun } & $\mathrm{CaO}$ & 4,1356 & 56,49 & 13,69 & 19,75 \\
\hline & & $\mathrm{Al}_{2}\left(\mathrm{SO}_{4}\right)_{3}$ & 2,5126 & 58,35 & 23,82 & 12,32 \\
\hline & & $\mathrm{FeSO}_{4}$ & 4,6750 & 36,16 & 6,56 & 0,26 \\
\hline & & Kontrol & 2,4258 & 63,67 & 8,16 & 11,87 \\
\hline \multirow{8}{*}{$2 \times$ Mordan } & \multirow{4}{*}{ Rayon } & $\mathrm{CaO}$ & 8,3725 & 49,80 & 18,77 & 27,92 \\
\hline & & $\mathrm{Al}_{2}\left(\mathrm{SO}_{4}\right)_{3}$ & 3,8702 & 73,14 & 10,13 & 15,62 \\
\hline & & $\mathrm{FeSO}_{4}$ & 4,3718 & 38,70 & 5,47 & 2,68 \\
\hline & & Kontrol & 1,7414 & 68,94 & 7,27 & 12,75 \\
\hline & \multirow{4}{*}{ Katun } & $\mathrm{CaO}$ & 4,9386 & 54,27 & 14,32 & 22,13 \\
\hline & & $\mathrm{Al}_{2}\left(\mathrm{SO}_{4}\right)_{3}$ & 1,3537 & 62,71 & 10,02 & 15,68 \\
\hline & & $\mathrm{FeSO}_{4}$ & 4,2130 & 44,11 & 5,21 & 0,89 \\
\hline & & Kontrol & 2,4258 & 63,67 & 8,16 & 11,87 \\
\hline
\end{tabular}

Sumber: Data Hasil Penelitian Sendiri

Penambahan mordan menghasilkan intensitas warna yang lebih tinggi dibandingkan tanpa mordan. Demikian juga dengan perlakuan dua kali pemordanan yang menghasilkan intensitas warna yang lebih tinggi bila dibandingkan dengan satu 
kali pemordanan. Mordan mempunyai peranan penting dalam meningkatkan intensitas warna. Kalsium oksida meningkatkan nilai K/S rata-rata $171,29 \%$, ferrous sulfat rata-rata $119,88 \%$, dan aluminium sulfat sebesar $34,26 \%$ (Tabel 2).

Peningkatan intensitas warna pada penggunaan logam $\mathrm{Ca}$ dan Fe lebih tinggi dibandingkan dengan logam Al. Kondisi ini sejalan dengan penelitian sebelumnya, dimana logam Al memiliki kemampuan kompleksitas yang lemah dibandingkan logam lainnya (Failisnur and Sofyan, 2016, 2014; Khattak et al., 2014). Tingginya intensitas warna berhubungan erat dengan kemampuan molekul pewarna membentuk kompleks logam dengan mordan yang bermuatan positif (Wanyama et al., 2010).

Hasil penelitian ini juga sejalan dengan penggunaan kulit luar bawang merah sebagai pewarna kain sutera dan Chamaecyparis lawsoniana sebagai pewarna wool. Ekstrak pewarna kulit luar bawang merah dengan mordan ferrous sulfat dan aluminium sulfat, serta Chamaecyparis lawsoniana dengan penambahan mordan pada berbagai konsentrasi dapat meningkatkan nilai K/S (Kilinc et al., 2015; Uddin, 2014). Selanjutnya ditambahkan bahwa logam mordan membentuk ikatan koordinat dengan kelompok karboksil (-COOH) selulosa dan $\left(-\mathrm{NH}_{2}\right)$ serat protein. Satu molekul pewarna dapat membentuk satu ikatan dengan satu molekul serat. Akan tetapi satu molekul mordan dapat membentuk dua atau lebih ikatan dengan molekul pewarna yang dapat menaikkan serapan terhadap zat warna (Ahmad et al., 2011; Uddin, 2014).

Kombinasi pewarnaan limbah cair gambir dan kayu secang dapat menghasilkan arah warna yang lebih bervariasi. Warna yang dihasilkan adalah merah muda, merah keunguan, coklat keunguan dan abu-abu kehitaman. Variasi warna berasal dari pewarna kombinannya yaitu kayu secang. Pigmen Brazilin $\left(\mathrm{C}_{16} \mathrm{H}_{14} \mathrm{O}_{5}\right)$ dalam kayu secang yang berwarna kuning, bila teroksidasi atau dengan adanya logam mordan dapat berubah menjadi brazilein $\left(\mathrm{C}_{16} \mathrm{H}_{12} \mathrm{O}_{5}\right)$ yang berwarna merah keunguan atau kecoklatan (Holinesti, 2007; Yusuf et al., 2017).

\section{Ketahanan Luntur Warna}

Kain rayon dan katun tanpa proses mordan mudah mengalami kelunturan karena proses pencucian (1-2). Penambahan logam mordan dapat meningkatkan nilai ketahanan luntur warnanya terhadap pencucian menjadi cukup sampai baik (3-4). Secara umum ketahanan luntur warna pada kain rayon dan katun setelah dua kali mordan terjadi peningkatan, kecuali pada kain katun dengan mordan Al dibandingkan dengan kontrol terjadi penurunan sebesar $44,2 \%$ (Tabel 3).

Penodaan warna yang terjadi karena proses pencucian pada kain rayon dan katun terhadap kain jenis lainnya (asetat, kapas, poliamida, poliester, akrilat, wool) bernilai cukup sampai sangat baik. Artinya tidak terjadi penodaan yang cukup berarti terhadap jenis kain lainnya. Secara umum mordan dapat meningkatkan ketahanan luntur warna kain yang diwarnai dengan limbah cair gambir dan kayu secang. Kemampuan logam mordan yang dapat membentuk dua atau lebih ikatan dengan molekul pewarna dapat meningkatkan nilai ketahanan luntur dari kain yang diwarnai (Uddin, 2014).

Penggunaan mordan kalsium oksida dan ferrous sulfat memberikan ketahanan luntur warna yang lebih baik (3-4) terhadap pencucian $40^{\circ} \mathrm{C}$, keringat asam, gosokan dan sinar dibandingkan aluminium sulfat. Sementara ferrous sulfat memberikan ketahanan luntur warna yang lebih baik terhadap sinar/cahaya.

Ketahanan luntur warna terhadap keringat dan gosokan pada umumnya bernilai cukup (3) sampai sangat baik (5) setelah kain dimordan (Tabel 4). Kompleksitas antara logam mordan, pewarna dan serat, dapat melindungi kromofor dari degradasi fotolitik. Foton yang diserap oleh Kelompok Kromofor menghilangkan energi dengan beresonansi dalam enam cincin molekul, sehingga melindungi pewarna (Khattak et al., 2014). Ketahanan luntur warna terhadap cahaya bernilai yang kurang sampai baik (2-4). Kebanyakan pewarna alam mempunyai ketahanan luntur warna yang kurang terhadap sinar, terutama dari golongan flavonoid (Cristea and Vilarem, 2006). 
Tabel 3. Ketahanan luntur warna terhadap pencucian

\begin{tabular}{|c|c|c|c|c|c|c|c|c|c|}
\hline \multirow{3}{*}{ Perlakuan } & \multirow{3}{*}{$\begin{array}{l}\text { Jenis } \\
\text { Kain }\end{array}$} & \multirow{3}{*}{$\begin{array}{l}\text { Jenis } \\
\text { Mordan }\end{array}$} & \multicolumn{7}{|c|}{ Ketahananan Luntur Warna Terhadap Pencucian $40^{\circ} \mathrm{C}$} \\
\hline & & & \multirow{2}{*}{$\begin{array}{l}\text { Perubahan } \\
\text { Warna }\end{array}$} & \multicolumn{6}{|c|}{ Penodaan Warna } \\
\hline & & & & Asetat & Kapas & Poliamida & Poliester & Akrilat & Wool \\
\hline \multirow{8}{*}{$\begin{array}{l}1 \mathrm{x} \\
\text { Mordan }\end{array}$} & \multirow{4}{*}{ Rayon } & $\mathrm{CaO}$ & 4 & $4-5$ & $4-5$ & $4-5$ & $4-5$ & $4-5$ & $4-5$ \\
\hline & & $\mathrm{Al}_{2}\left(\mathrm{SO}_{4}\right)_{3}$ & 3 & $4-5$ & $4-5$ & $4-5$ & $4-5$ & $4-5$ & $4-5$ \\
\hline & & $\mathrm{FeSO}_{4}$ & 3 & $4-5$ & $4-5$ & $4-5$ & $4-5$ & $4-5$ & $4-5$ \\
\hline & & Kontrol & $1-2$ & 3 & $2-3$ & 3 & 3 & 3 & $2-3$ \\
\hline & \multirow{4}{*}{ Katun } & $\mathrm{CaO}$ & 3 & $4-5$ & $4-5$ & $4-5$ & $4-5$ & $4-5$ & $4-5$ \\
\hline & & $\mathrm{Al}_{2}\left(\mathrm{SO}_{4}\right)_{3}$ & 3 & $4-5$ & $4-5$ & $4-5$ & $4-5$ & $4-5$ & $4-5$ \\
\hline & & $\mathrm{FeSO}_{4}$ & 3 & $4-5$ & $4-5$ & $4-5$ & $4-5$ & $4-5$ & $4-5$ \\
\hline & & Kontrol & $1-2$ & $1-2$ & $1-2$ & 2 & 2 & 2 & $1-2$ \\
\hline \multirow{8}{*}{$\begin{array}{l}2 x \\
\text { Mordan }\end{array}$} & \multirow{4}{*}{ Rayon } & $\mathrm{CaO}$ & 4 & $4-5$ & $4-5$ & $4-5$ & $4-5$ & $4-5$ & $4-5$ \\
\hline & & $\mathrm{Al}_{2}\left(\mathrm{SO}_{4}\right)_{3}$ & $3-4$ & $4-5$ & $4-5$ & $4-5$ & $4-5$ & $4-5$ & $4-5$ \\
\hline & & $\mathrm{FeSO}_{4}$ & $3-4$ & $4-5$ & $4-5$ & $4-5$ & $4-5$ & $4-5$ & $4-5$ \\
\hline & & Kontrol & $1-2$ & 3 & $2-3$ & 3 & 3 & 3 & $2-3$ \\
\hline & \multirow{4}{*}{ Katun } & $\mathrm{CaO}$ & 3 & $4-5$ & $4-5$ & $4-5$ & $4-5$ & $4-5$ & $4-5$ \\
\hline & & $\mathrm{Al}_{2}\left(\mathrm{SO}_{4}\right)_{3}$ & 2 & $4-5$ & $4-5$ & $4-5$ & $4-5$ & $4-5$ & $4-5$ \\
\hline & & $\mathrm{FeSO}_{4}$ & 3 & $4-5$ & $4-5$ & $4-5$ & $4-5$ & $4-5$ & $4-5$ \\
\hline & & Kontrol & $2-3$ & 2 & $1-2$ & 2 & 2 & 2 & $1-2$ \\
\hline
\end{tabular}

Sumber: Data Hasil Penelitian Sendiri

Tabel 4. Ketahanan luntur warna terhadap keringat asam, gosokan kering dan sinar

\begin{tabular}{|c|c|c|c|c|c|c|c|c|c|c|}
\hline \multirow{4}{*}{ Perlakuan } & \multirow{4}{*}{$\begin{array}{l}\text { Jenis } \\
\text { Kain }\end{array}$} & \multirow{4}{*}{$\begin{array}{l}\text { Jenis } \\
\text { Mordan }\end{array}$} & \multicolumn{8}{|c|}{ Ketahanan Luntur Warna } \\
\hline & & & \multicolumn{6}{|c|}{ Keringat Asam } & \multirow{3}{*}{ Gosokan } & \multirow{3}{*}{ Sinar } \\
\hline & & & \multirow{2}{*}{$\begin{array}{l}\text { Peru- } \\
\text { bahan } \\
\text { Warna }\end{array}$} & \multicolumn{5}{|c|}{ Penodaan Warna } & & \\
\hline & & & & Kapas & Poliamida & Poliester & Akrilat & Wool & & \\
\hline \multirow{8}{*}{$\begin{array}{l}1 \mathrm{x} \\
\text { Mordan }\end{array}$} & \multirow{4}{*}{ Rayon } & $\mathrm{CaO}$ & 4 & 3 & 3 & $4-5$ & $4-5$ & $4-5$ & $4-5$ & $3-4$ \\
\hline & & $\mathrm{Al}_{2}\left(\mathrm{SO}_{4}\right)_{3}$ & 4 & 3 & 3 & $4-5$ & $4-5$ & 4 & $4-5$ & $3-4$ \\
\hline & & $\mathrm{FeSO}_{4}$ & 4 & 3 & 3 & $4-5$ & $4-5$ & $4-5$ & $4-5$ & 4 \\
\hline & & Kontrol & 4 & 3 & 3 & $4-5$ & $4-5$ & 4 & $4-5$ & 3 \\
\hline & \multirow{4}{*}{ Katun } & $\mathrm{CaO}$ & $4-5$ & 3 & 3 & 4 & 4 & 4 & $4-5$ & 3 \\
\hline & & $\mathrm{Al}_{2}\left(\mathrm{SO}_{4}\right)_{3}$ & 3 & 3 & 3 & $4-5$ & $4-5$ & $4-5$ & $4-5$ & $3-4$ \\
\hline & & $\mathrm{FeSO}_{4}$ & $4-5$ & 3 & 3 & 4 & 4 & 4 & $4-5$ & $3-4$ \\
\hline & & Kontrol & 4 & 3 & 3 & 4 & 4 & 4 & $4-5$ & $3-4$ \\
\hline \multirow{8}{*}{$\begin{array}{l}2 x \\
\text { Mordan }\end{array}$} & \multirow{4}{*}{ Rayon } & $\mathrm{CaO}$ & 4 & 4 & 4 & $4-5$ & $4-5$ & 4 & $4-5$ & 3 \\
\hline & & $\mathrm{Al}_{2}\left(\mathrm{SO}_{4}\right)_{3}$ & 4 & 4 & $4-5$ & $4-5$ & $4-5$ & $4-5$ & $4-5$ & 3 \\
\hline & & $\mathrm{FeSO}_{4}$ & 4 & 3 & 3 & $4-5$ & $4-5$ & $4-5$ & $4-5$ & 4 \\
\hline & & Kontrol & 4 & 3 & 3 & $4-5$ & $4-5$ & 4 & $4-5$ & 3 \\
\hline & \multirow{4}{*}{ Katun } & $\mathrm{CaO}$ & 3 & 4 & 4 & 4 & 4 & 4 & $4-5$ & $2-3$ \\
\hline & & $\mathrm{Al}_{2}\left(\mathrm{SO}_{4}\right)_{3}$ & $3-4$ & 4 & 4 & $4-5$ & $4-5$ & $4-5$ & $4-5$ & $2-3$ \\
\hline & & $\mathrm{FeSO}_{4}$ & 4 & 3 & 3 & $4-5$ & $4-5$ & $4-5$ & $4-5$ & 3 \\
\hline & & Kontrol & 4 & 3 & 3 & $4-5$ & $4-5$ & $4-5$ & $4-5$ & 3 \\
\hline
\end{tabular}

Sumber: Data Hasil Penelitian Sendiri

\section{KESIMPULAN}

Kombinasi pewarna limbah cair gambir dengan secang menggunakan mordan $\left.\mathrm{CaO}, \mathrm{Al}_{2} \mathrm{SO}_{4}\right)_{3}$ dan $\mathrm{FeSO}_{4}$ memberikan arah warna yang lebih bervariasi dari coklat muda menjadi merah muda, merah kecoklatan, merah keunguan, coklat keunguan sampai coklat kehitaman. Mordan $\left.\mathrm{Al}_{2} \mathrm{SO}_{4}\right)_{3}$ menghasilkan warna yang terang (Ligthness), sementara $\mathrm{FeSO}_{4}$ memberikan warna yang gelap (darkness). 
Perbedaan jenis serat yang diwarnai memberikan tingkat penyerapan warna (intensitas) yang berbeda. Perlakuan dua kali mordan dapat memberikan intensitas dan ketahanan luntur warna terhadap pencucian, keringat asam, gosokan dan sinar yang lebih tinggi dibandingkan satu kali mordan dan tanpa mordan.

\section{UCAPAN TERIMA KASIH}

Kami sampaikan terima kasih kepada Marlusi, Sulastri, Prasemiati Ningsih dan Rismardi atas kerjasamanya yang telah membantu pelaksanaan penelitian.

\section{DAFTAR PUSTAKA}

Ahmad, W.Y.W., Rahim, R., Ahmad, M.R., Kadir, M.I.A., Misnon, M.I., 2011. The application of Gluta aptera wood ( Rengas ) as natural dye on silk and cotton fabrics. Univers. J. Environ. Res. Technol. 1, 545-551.

Arbain, A., Sy, S., Kasim, A., 2014. Perilaku krom dalam limbah cair penyamakan kombinasi krom-gambir dan krom-mimosa pada penyamakan kulit. J. Litbang Ind. 4, 59-66. doi:10.24960/jli.v4i1.646.59-66

Cristea, D., Vilarem, G., 2006. Improving light fastness of natural dyes on cotton yarn. Dye. Pigment. 70, 238-245. doi:10.1016/j.dyepig.2005.03.006

Failisnur, Sofyan, 2016. Pengaruh suhu dan lama pencelupan benang katun pada pewarnaan alami dengan ekstrak gambir (Uncaria gambir Roxb). J. Litbang Ind. 6, 25-37. doi:10.24960/jli.v6i1.716.25-37

Failisnur, Sofyan, 2014. Sifat tahan luntur dan intensitas warna kain sutera dengan pewarna alam gambir (Uncaria gambir Roxb) pada kondisi pencelupan dan jenis fiksator yang berbeda. J. Litbang Ind. 4, 1-8. doi:10.24960/jli.v4i1.634.1-8

Failisnur, Sofyan, Hermianti, W., 2017. Pemanfaatan limbah cair pengempaan gambir untuk pewarnaan kain batik. J. Litbang Ind. 7, 19-28. doi:10.24960/jli.v7i1.2695.19-28
Failisnur, Yeni, G., 2013. Stabilization of gambier process wastewater and its aplication as silk dye. Biopropal Ind. 4, 7-16.

Fardhayanti, D.S., Riski, R.D., 2015. Pemungutan brazilin dari kayu secang (Caesalpinia sappan L) dengan metode maserasi dan aplikasinya untuk pewarna kain. J. Bahan Alam Terbarukan 4, 8-17. doi:10.15294/jbat.v4i1.3768

Fu, L.C., Huang, X.A., Lai, Z.Y., Hu, Y.J., Liu, H.J., Cai, X.L., 2008. A new 3benzylchroman derivative from Sappan Lignum (Caesalpinia sappan). Molecules 13, 1923-1930. doi:10.3390/molecules 13081923

Holinesti, R., 2007. Studi pemanfaatan pigmen brazilein kayu secang (Caesalpinia sappan L.) sebagai pewarna alami serta stabilitasnya pada model pangan. Bogor Agricultural University., Bogor.

Khattak, S.P., Rafique, S., Hussain, T., Ahmad, B., 2014. Optimization of fastness and tensile properties of cotton fabric dyed with natural extracts of Marigold flower (Tagetes erecta) by pad-steam method. Life Sci. J. 11, 5260.

Kilinc, M., Canbolat, S., Merdan, N., Dayioglu, H., Akin, F., 2015. Investigation of the color, fastness and ntimicrobial properties of wool fabrics dyed with the natural dye extracted from the cone of Chamaecyparis lawsoniana. Procedia - Soc. Behav. Sci. 195, 2152-2159. doi:10.1016/j.sbspro.2015.06.281

Kumaresan, 2013. Comparison of fastness properties and colour strength of dyed cotton fabrics with eco-friendly natural dyes. Exp. 8, 483-489.

Mirjalili, M., Karimi, L., 2013. Extraction and characterization of natural dye from green walnut shells and its use in dyeing polyamide: Focus on antibacterial properties. J. Chem. 2013. doi:10.1155/2013/375352

Moiz, A., Aleem Ahmed, M., Kausar, N., Ahmed, K., Sohail, M., 2010. Study 
the effect of metal ion on wool fabric dyeing with tea as natural dye. J. Saudi Chem. Soc. 14, 69-76. doi:10.1016/j.jscs.2009.12.011

Prayitno, R.E., Wijana, S., Diyah, B.S., 2014. Pengaruh bahan fiksasi terhadap ketahanan luntur dan intensitas warna kain mori batik hasil pewarnaan daun Alpukat (Persea americana Mill.).

Punrattanasin, N., Nakpathom, M., Somboon, B., Narumol, N., Rungruangkitkrai, N., Mongkholrattanasit, R., 2013. Silk fabric dyeing with natural dye from mangrove bark (Rhizophora apiculata Blume) extract. Ind. Crops Prod. 49, 122-129.

doi:10.1016/j.indcrop.2013.04.041

Rosyida, A., 2015. Pengaruh variasi $\mathrm{pH}$ dan fiksasi pada pewanaan kain kapas dengan zat warna alam dari kayu nangka, in: Prosiding Seminar Nasional 4th UNS SME's Summit \& Awards 2015. pp. 101-112.

Samanta, A.K., Agarwal, P., 2009. Application of natural dyes on textiles. Indian J. Fibre Text. Res. 34, 384399.

Samanta, A.K., Konar, A., 2011. Dyeing of textiles with natural dyes. Nat. Dye. 29-56. doi:10.5772/21341

Silfia, S., Muchtar, H., Failisnur, F., 2015. Influence of difference percentage of glycerin and concentration of solutions of the gambir extract on physicals and content tannins ink stamp. J. Litbang Ind. 5, 53-59.

Sofyan, S., Failisnur, F., 2017. Reuse of liquid waste from textile dyeing with natural dyes gambier (Uncaria gambir Roxb.) for cotton yarn dyeing. ARPN J. Eng. Appl. Sci. 12, 5313-5318.

Sofyan, S., Failisnur, F., 2016. Gambier (Uncaria gambir Roxb) as a Natural Dye of Silk, Cotton, and Rayon Batik Fabrics. J. Litbang Ind. 6, 89-98. doi:10.24960/jli.v6i2.1721.89-98

Sofyan, Failisnur, Sy, S., 2015. Pengaruh perlakuan limbah dan jenis mordan kapur, tawas, dan tunjung terhadap mutu pewarnaan kain sutera dan katun menggunakan limbah cair gambir (uncaria gambir roxb). J. Litbang Ind. 5, 79-89. doi:10.24960/jli.v5i2.668.79-89

Sugiyanto, R.N., Rahmadani Putri, S., Damanik, F.S., Sasmita, G.M.A., 2013. Aplikasi kayu secang (Caesalpinia sappan L.) dalam upaya prevensi kerusakan DNA akibat paparan zat potensial karsinogenik melalui MNPCE assay, in: Diltilabmas (Ed.), E-Proceeding PimNas. Ditjen DIKTI RI.

Uddin, M.G., 2014. Effects of different mordants on silk fabric dyed with onion outer skin extracts. J. Text. 2014, 1-8. doi:10.1155/2014/405626

Wanyama, P.A.G., Kiremire, B.T., Ogwok, P., Murumu, J.S., 2010. The effect of different mordants on strength and stability of colour produced from selected dye-yielding plants in Uganda. laast 1, 81-92.

Yeni, G., Syafruddin, D., Kasim, A., Amos, 2016. Tannic ability test of cube black and liquid waste of gambier to leather tanned quality. J. Litbang Ind. 6, 7382.

Yeni, G., Syamsu, K., Mardliyati, E., Muchtar, H., 2017. Penentuan teknologi proses pembuatan gambir murni dan katekin terstandar dari gambir asalan. J. Litbang Ind. 7, 1-10. doi:10.24960/jli.v7i1.2846.1-10

Yusuf, M., Mohammad, F., Shabbir, M., 2017. Eco-friendly and effective dyeing of wool with anthraquinone colorants extracted from Rubia cordifolia roots: Optimization, colorimetric and fastness assay. J. King Saud Univ. - Sci. 29, 137-144. doi:10.1016/j.jksus.2016.06.005

Zhao, Q., Feng, H., Wang, L., 2014. Dyeing properties and color fastness of cellulase-treated flax fabric with extractives from chestnut shell. J. Clean. Prod. 80, 197-203. doi:10.1016/j.jclepro.2014.05.069 